УДК 330.1:330.34

Слісєєва Людмила, доктор економічних наук, доцент, Волинський національний університет імені Лесі Українки, кафедра економіки та природокористування, м. Луцьк, ORCID ID 0000-0002-8801-3329

https://doi.org/10.29038/2786-4618-2021-02-24-33 e-mail: Yelisieieva.Liudmyla@vnu.edu.ua

\title{
МЕТОДОЛОГІЧНІ ПІХОДИ ДО АНАЛІЗУ СОЦІАЛЬНОГО КАПІТАЛУ ЯК ЕКОНОМІЧНОГО ІНСТИТУТУ НА МІКРО-, МАКРОРІВНЯХ ТА ЕКОНОМІЧНИХ НАСЛІДКІВ СИНЕРГІЇ КООПЕРАТИВНОЇ ВЗАЕМОДІЇ
}

\begin{abstract}
На основі синтезованого підходу через поєднання інституційно-еволюційної, біхевіористичної методології та синергетичного підходу визначено інституційну природу соціального капіталу, який конституюється неформальними (спільними цінностями, укоріненими соціальними нормами та довірою) й формальними (мережевими зв'язками та моделями соціальної структури) субінститутами, та його роль як метаінституту, що є дієвим механізмом трансформації інституційної архітектоніки господарських систем та створення сприятливого середовища для формування нових інститутів та організацій, які надалі визначають цілі, моделі, характер економічного розвитку.
\end{abstract}

Ключові слова: соціальний капітал, економічний інститут, економічний розвиток, синергія кооперативної взаємодії.

Елисеева Людмила, доктор экономических наук, доцент, Волынский национальный университет имени Леси Украинки, кафедра экономики и природопользования, г. Луцк

\section{МЕТОДОЛОГИЧЕСКИЕ ПОДХОДЫ К АНАЛИЗУ СОЦИАЛЬНОЙ КАПИТАЛА КАК ЭКОНОМИЧЕСКОГО ИНСТИТУТА НА МИКРО-, МАКРОУРОВНЯХ И ЭКОНОМИЧЕСКИХ ПОСЛЕДСТВИЙ СИНЕРГИИ КООПЕРАТИВНОГО ВЗАИМОДЕЙСТВИЯ}

\begin{abstract}
На основании синтезированного подхода через сочетание институционально-эволюционной, бихевиористичной методологии и синергетического подхода определены институциональная природа социального капитала, который конституируется неформальными (общими ценностями, укорененными социальными нормами и доверием) и формальными (сетевыми связями и моделями социальной структуры) субинститутами, и его роль как метаинститута, что является действенным механизмом трансформации институциональной архитектоники хозяйственных систем и создание благоприятной среды для формирования новых институтов и организаций, которые в дальнейшем определяют цели, модели, характер экономического развития.
\end{abstract}

Ключевые слова: социальный капитал, экономический институт, экономическое развитие, синергия кооперативного взаимодействия.

Yelisieieva Liudmyla,

Ph. D. in Economics, Associate Professor

Lesya Ukrainka Volyn National Unaversity Department of Economics and Nature Management, Lutsk 


\section{METHODOLOGICAL APPROACHES TO THE ANALYSIS OF SOCIAL CAPITAL AS AN ECONOMIC INSTITUTE AT MICRO-, MACRO-LEVELS AND ECONOMIC CONSEQUENCES OF SYNERGY OF COOPERATIVE INTERACTION}

On the basis of the synthesized approach through a combination of institutional-evolutionary, behavioral methodology and synergetic approach the institutional nature of social capital is defined, which is constituted by informal (common values, rooted social norms and trust) and formal (network connections and models of social structure, its subinstitutions) role as a meta-institution, which is an effective mechanism for transforming the institutional architecture of economic systems and creating a favorable environment for the formation of new institutions and organizations that further define the goals, models, nature of economic development.

The methodological bases of the analysis of the institution of social capital have been improved through complex measurement of its components and their interrelation with dynamics of macroeconomic indicators (GDP, the structure of state budget expenditures, the volume of internal investments, etc.) and indicators of entrepreneurship development (number and dynamics of business entities creation, business sector structure, the level of capitalization and socialization of business), allowing to optimize the methodology for assessing the economic potential of the institution of social capital and develop recommendations to increase the economic return from its use as a resource of the national economy. The determinants that condition the specifics of the productive use of the economic potential of the social capital institution in the national economy in the context of global transformations are systematized. The factors of deformation of the social capital institution in the national economy are revealed, which is a consequence of the previous trajectory of development and leads to the transformation of social capital into a predominantly extractive institution.

Key words: social capital, economic institute, economic development, synergy of cooperative interaction.

Постановка проблеми та її значення. Постіндустріальна економіка характеризується високим рівнем динамізму та емерджентності, що спричиняє появу нових явищ, процесів та трендів суспільного розвитку, які потребують наукового осмислення та концептуалізації. Таку переоцінку не завжди вдається здійснити на засадах неокласичних підходів, оскільки на перебіг економічних процесів все більше впливають неекономічні чинники (у тому числі соціальні норми, цінності, культура), які тривалий час недооцінювалися економістами. Це підштовхує останніх до розширення об'єкту досліджень та зміщення фокусу з природного, фізичного, фінансового на людський, інтелектуальний та соціальний капітали, які здатні конвертуватися в економічний та забезпечити отримання вигод індивідам, групам і суспільству загалом. Тому в сучасних умовах пришвидшення темпів глобалізації, стрімкого розвитку інформаційних технологій, формування мережевого суспільства виникає необхідність модернізації існуючої економічної парадигми 3 точки зору здатності загальноприйнятої економічної теорії релевантно пояснити сучасні процеси в міжнародній та національній економіці. Окремі припущення, які є ядром та захисним поясом неокласичної теорії, уже не відповідають сучасним реаліям. Серед них - стабільність та екзогенність уподобань, повна поінформованість економічних суб'єктів, відсутність трансакційних витрат під час економічного обміну, чітка специфікація прав власності, існування досконалої конкуренції тощо. У зв’язку з цим сформувалася потреба в критичному переосмисленні альтернативних напрямів розвитку економічної думки для того, щоб розширити науковий горизонт і збагатити методологічний інструментарій економістів.

Аналіз останніх досліджень і публікацій. В Україні перші дослідження соціального капіталу 3'явилися на початку XXI ст. Серед них - праці О. Балакірєвої, Б. Буркинського, 3. Галушки, Н. Гражевської, О. Петроє та ін. Попри вагомі наукові результати вище зазначених робіт, на нашу думку, в сучасній економічній науці недостатньо систематизовано наукові погляди на роль соціального капіталу в економічному розвитку.

Мета і завдання статті. Метою статті $є$ дослідження методологічних підходів до аналізу соціального капіталу як економічного інституту на мікро-, макрорівнях та економічних наслідків синергії кооперативної взаємодії. 
Виклад основного матеріалу та обгрунтування отриманих результатів дослідження. На думку відомого методолога Б. Колдуела, "не існує ніякого універсального й логічно досконалого методу оцінки якості теорій”, тобто єдино правильної наукової методології. У зв’язку з цим наявність якісно відмінних наукових уявлень про економічну реальність - важлива риса сучасної економічної науки, що $є$ відповіддю на багатовимірність економіки як об'єкту пізнання. За твердженням відомого економіста XX ст. Дж. Хікса "наші теорії як інструменти аналізу діють подібно до шор ... це проміння світла, які висвітлюють одні частини об'єкту й залишають у сутінках інші" [11, с. 56]. Погоджуючись із ученим, вважаємо за необхідне в дослідженнях дотримуватися методологічного плюралізму, який передбачає використання підходів різних наукових шкіл, поліваріантність економічного мислення та дозволяє користуватися їх інструментарієм для всебічного вивчення об'єкту дослідження.

На сучасному етапі суспільного розвитку найбільш релевантною для вивчення кооперативної взаємодії, соціального капіталу на мікро- та макрорівнях, на нашу думку, $є$ постнекласична методологія дослідження соціоекологоекономічних процесів [2]. На думку В. Степанова, до переваг останньої належать: 1) зростання ролі міждисциплінарних (інтегрованих) підходів, що дозволяє всебічно дослідити суспільний процес чи явище, долаючи методологічні лакуни окремих дисциплін; 2) посилення “людської складової” у методах дослідження та цивілізаційному сенсі, унаслідок чого людина стає ціллю, а не лише ресурсом економічного розвитку; 3) вивчення надскладних систем, здатних до саморозвитку, що більше відповідає сучасним реаліям; 4) нелінійність, нестійкість, коеволюція, самоорганізація як ключові характеристики економічного розвитку XXI ст. тощо. Серед методологічних принципів постнекласичної науки він виділив: 1) принцип дуалістичного погляду на глобальні процеси, відповідно до якого закріплюються уявлення про світ як єдину цілісну структуру, що самостійно розвивається, а, з іншого, - як нестабільний, нестійкий, нерівноважний, хаосогенний, невизначений; 2) принцип цілісності, що передбачає багатостороннє вивчення суспільних явищ i процесів за допомогою застосування методів різних наук; 3) принцип коеволюції взаємообумовленість змін різних систем; 4) принцип пріоритетності дослідження історичного розвитку систем тощо [9, с. 57-58]. Названі принципи постнекласичної науки та інтегрований міждисциплінарний підхід до всебічного вивчення соціального капіталу як суспільного феномену уможливлюють використання методів та результатів досліджень не лише з економіки, а й соціології, історії, політики, права тощо. Це частково дозволяє подолати обмеженість вузькопрофільних досліджень і розкрити дану проблему з більш широкої перспективи.

Методологія постнекласичної науки корелюється 3 неортодоксальною інноваційноеволюційною теорією розвитку Й. Шумпетера. У своїх ранніх працях Й. Шумпетер розрізняв два типи розвитку: “статика" та “динаміка". Перша орієнтована на відтворення традиційної структури виробництва та не здатна значно збільшити сукупний продукт та підвищити рівень суспільного добробуту. На його думку, це “просте збільшення економіки, яке виявляється у збільшенні населення та багатства ... воно не передбачає жодних якісно нових явищ, а лише процеси адаптації такого самого типу, як зміни у звичних умовах" [13, с. 73]. “Справжнім” економічним розвитком він вважав “динаміку”, обумовлену поширенням інновацій та інноваційного підприємництва. Економічна динаміка грунтується на поширенні нововведень, трансформації економічної структури, взаємозв”язків між “новим” та “старим” виробництвом тощо. Й. Шумпетер виділив п'ять видів інновацій: виробництво нових товарів, освоєння нових ринків, застосування нових технологій i техніки, відкриття нових джерел сировини та нову галузеву організацію. Їх джерелом вважав економічне новаторство, яке $\epsilon$ економічною функцією підприємця. Водночас саме інновації $\epsilon$ ключовим чинником “творчої руйнації” - здатності економічної системи видаляти застарілі елементи та оновлювати економічні структури. Й. Шумпетер стверджував, що капіталістичній системі притаманна тенденція до саморуйнації, яка на початковому етапі може виявлятися у формі “гальмування прогресу”, коли система “не тільки руйнує власну інституційну структуру, а й створює умови для іншої” [12, с. 69-70]. Така руйнація відбувається завдяки інноваційному підприємництву. Підприємець постійно перебуває в пошуку нових способів використання ресурсів. Завдяки цьому він може отримати високий прибуток, бо нові технології забезпечують йому тимчасову монополію. За Й. Шумпетером нові комбінації починають реалізуватися у нових компаніях, які “не виростають зі старих, а починають працювати поруч з ними” [12, с. 76]. 3 часом конкуренція та наслідування 
підривають цю монопольну ринкову владу й створюють стимул до нових інновацій. Для відновлення можливості одержання монопольного прибутку визначальною $\epsilon$ конкуренція нових товарів, технології, організаційних форм тощо. Унаслідок інновацій старі форми організації витісняються на користь нових, зумовлюючи процес “творчої руйнації”. Перешкоди “творчій руйнації” можуть чинити: 1) “сама природа усталених мисленнєвих звичок, їхня енергоощадна функція”, які “стають гальмом, коли вичерпують запас своєї корисності” [12, с. 93]; 2) соціальний остракізм, проте з часом глибша диференціація послаблює цей супротив; 3) політичні та економічні правила. За Й. Шумпетером неформальні правила можуть суперечити впровадженню інновацій або навпаки функціонувати в симбіозі, оскільки підприємницька функція також може “формувати стиль життя чи системи моральних і естетичних цінностей” [12, с. 86], змінюючи ментальні конструкції та соціальні норми в суспільстві.

У рамках методології постнекласичної науки зростає значення системного, інституційноеволюційного, біхевіористського, синергетичного, логіко-історичного, діалектичного та міждисциплінарного підходів 3 метою більш глибокого вивчення суспільних явищ і процесів, оскільки економічна логіка часто вбудована в соціальні, політичні чи культурні контексти.

Дослідження природи та економічної ролі соціального капіталу можливе лише за умов системного підходу до аналізу цього складного соціоекономічного феномену, згідно 3 яким соціально-економічні процеси і явища розглядаються як єдина соціальна система, яка включає в себе велику кількість самостійних підсистем. Такий підхід, обгрунтований свого часу Я. Корнаї [4, с. 1734], на відміну від традиційної економічної теорії, дозволяє краще відслідкувати взаємодію різних явищ, економічних процесів, інститутів тощо. Його сутність розкривають наступні положення: 1) об'єкт вивчення є цілісною системою, що взаємодіє з іншими, у тому числі системою, до якої він входить; 2) система $є$ наслідком взаємодії економіки, політики та культури; 3) вона розвивається відповідно до законів власної еволюції, так і прийнятих формальних правил; 4) у всіх систем є свої недоліки, які притаманні саме їм. За тверженням Я. Корнаї, “дослідник, який притримується системної парадигми чи системного підходу, повинен шукати пояснення в історіі”, насамперед в історії розвитку цієї системи. Основна увага фокусується на "інститутах, які виникли історично й розвиваються еволюційним шляхом" (такі інститути можна назвати “системними”) та "системних подіях", яким відповідають значні зміни, глибокі трансформації системи. Такий методологічний підхід дозволяє розглядати соціальний капітал як системний інститут (метаінститут), який змінюється внаслідок саморозвитку та взаємодії з іншими інститутами та системою загалом.

Однією із ключових методологічних засад вивчення розвитку соціального капіталу $є$ його дослідження за допомогою інституційно-еволюційного підходу [1]. Його застосування в дослідженні частково дозволяє подолати обмеження традиційного економічного аналізу, а саме: 1) відмовитися від теорії "економічного індивіда" на користь концепції “інституційної людини", яка визнає історичну мінливість уподобань і поведінки економічних агентів; 2) спиратися на припущення обмеженої раціональності, у рамках якої економічний суб'єкт не здатний проаналізувати усі наявні альтернативи й вибирає найкращий із відомих варіантів; 3) включити в економічний аналіз поняття трансакційних витрат, які супроводжують взаємодію економічних агентів та впливають на іiі ефективність, що актуалізує проблему формування інституційної структури, яка б сприяла скороченню такої групи витрат; 4) припущення можливості опортуністичної поведінки, що обумовлюється неповнотою інформації тощо.

Розглядаючи соціальний капітал із позицій інституційної теорії, ми вважаємо, що інститути: 1) виконують роль генів в економіці, 2) мають значення для обгрунтування поведінки економічних суб'єктів і розміщення ресурсів, 3) можна вивчати через призму їх впливу на рішення, що ухвалюють економічні суб'єкти, 4) обмежують набір альтернатив, але й створюють нові можливості, 5) піддаються впливу з боку індивідів та їх груп, 6) є структурами, які впорядковують взаємодію між людьми, що вимагає дослідження процесів обробки інформації, отримання й використання знання, структури стимулів і контролю в різних формах економічних організацій, що мають мережеву структуру тощо.

Складність застосування інституційно-еволюційного підходу в нашому дослідженні обумовлена тим, що в економічній науці немає уніфікованого трактування поняття “інститут”: у Дж. Коммонса це колективні дії щодо контролю та розширення індивідуальної дії; В. Мітчелла - домінантні 
стандартизовані суспільні звички; В. Ніла - регулярна, патернізована поведінка економічних суб'єктів у суспільстві тощо. Ми притримуємося дефініції Нобелівського лауреата Д. Норта, згідно 3 якою інститути - правила та механізми, що забезпечують їх виконання; норми поведінки, які структурують повторювальні взаємодії між людьми [6, с. 17]. Звідси вважаємо, що соціальний капітал - інститут, сконструйовані людьми обмеження, які структурують людську взаємодію, визначають умови алокації ресурсів та можливості для економічної активності учасників мереж; правила гри, які використовують економічні агенти для того, щоб організувати свої дії. Саме включеність індивідів у сферу впливу таких правил у рамках груп вузьких чи широких інтересів створює умови для формування соціального та економічного порядку.

Соціальний капітал, маючи ознаки насамперед неформального інституту, що виявляється через довіру, цінності, норми суспільної поведінки, може водночас реалізовуватись через функціонування формальних інституційних механізмів та організацій (організації та мережі, через які відбувається комунікація). Тому важливо досліджувати його специфіку й вплив на економічні процеси як у неформальному вимірі, так і через призму формалізованих норм, організацій та мереж. У зв’язку 3 цим ми переконані, що соціальний капітал - інститут, який конституюється неформальними (спільними цінностями, укоріненими соціальними нормами та довірою) і формальними (мережевими зв'язками та моделями соціальної структури) субінститутами.

До сьогодні у науковій літературі не існує уніфікованого визначення поняття “неформальний інститут”. Навіть Нобелівський лауреат Д. Норт, ініціатор системного дослідження неформальних інститутів економістами, обмежився окремими прикладами, віднісши до неформальних інститутів традиції, табу, кодекси поведінки, санкції тощо. Згідно з дослідженнями Р. Собел і К. Койн неформальні правила включають норми, культуру, звички, які забезпечені не формальним правом, а суспільними традиціями; Л. Стір, К. Сена - “неписані правила, соціальні норми та мережі”. Наша наукова позиція відносно соціального капіталу частково корелюється 3 науковими ідеями Нобелівського лауреата Дж. Стігліца, який ототожнив неформальні інститути та соціальний капітал, а останній - із такими неринковими інститутами як довіра, репутація, цінності.

За допомогою структурно-функціонального аналізу ми розглядаємо соціальний капітал як сукупність формальних (мережевих структур) i неформальних (довіра та соціальні норми) субінститутів. Довіра та соціальні норми - набір неформальних правил, які поділяються членами спільноти й використовуються на практиці. Такі правила склалися в суспільстві завдяки усвідомленню індивідами та їх групами базових принципів життєдіяльності - цінностей. Стійкі стереотипи та цінності формують ментальні моделі, на основі яких складаються норми. Соціальні норми є кодексом поведінки спільноти та рутинами з позиції еволюційної економіки. Уперше поняття "рутина" було запропоноване засновниками еволюційної теорії Р. Нельсоном і С. Вінтером для означення стійких зразків поведінки, які формуються внаслідок звикання до певної послідовності дій, що з часом стає неусвідомленим правилом і відтворюється автоматично [5]. Ми можемо розглядати такі рутини як особливу форму інститутів (субінститути), які задають рамки й патерни для господарської поведінки економічних суб'єктів 3 урахуванням існуючих фізичних, соціальних технологій, характерних певному господарському порядку й домінантному способу економічної координації. Через це вважаємо за необхідне використання біхевіористського підходу під час дослідження інституту соціального капіталу, щоб виявити взаємозв'язок між поведінковими та економічними ефектами.

Соціальні норми нерозривно пов'язані з очікуваннями та зобов'язаннями членів спільноти. Американська дослідниця К. Біччіері розмежовує два типи очікувань, які мають бути досягнуті для колективного дотримання соціальної норми. Нормативні пов’язані з тим, що, на думку індивіда, від нього очікують члени спільноти; емпіричні формуються на підставі спостереження за поведінкою інших в аналогічних ситуаціях. Відповідність між собою таких очікувань обумовлює колективне наслідування соціальної норми.

Колективне прийняття та дотримання соціальних норм обумовлює формування стійких зв’ язків між членами спільноти, створення формальних структур - мереж. Структура мережі, у яку залучені економічні агенти, не лише визначає канали їх взаємодії, але й формує стимули до певної моделі поведінки. Як бачимо, такі мережі визначають обмеження для економічної поведінки та створюють 
нові можливості для індивідів у рамках спільнот. У зв’язку з цим ми розглядаємо мережі як ще одну складову - субінститут соціального капіталу.

Не менш важливе значення для дослідження соціального капіталу як інституту має аналіз механізму виконання неформальних правил. Він включає методи, важелі та інструменти. До основних методів належать примус чи заохочення. У першому випадку інструментами є засудження, вилучення зі складу спільноти, позбавлення порушника певних прав, остракізм друзів чи сусідів, втрата репутації тощо. Найгіршою формою колективного покарання вважається остракізм. Метод “пряника" передбачає заохочення дотримання соціальних норм і правил через покращення репутації індивіда, отримання інших соціальних дивідендів. Важелями механізму виконання норм є економічні та соціальні. За відсутності економічної люди можуть керуватися соціальною мотивацією, оскільки соціальний статус і суспільне визнання є індивідуальними неколективними благами. Проте соціальні мотиви відіграють істотну роль лише в малих групах; у великих вони стають важливими лише тоді, коли, за М. Олсоном, спільнота є федерацією малих груп [7, с. 57].

Як і будь-який інститут, соціальний капітал має інформаційну природу, завдяки чому індивіди отримують інформацію про санкціоновані й заборонені дії та формують свої поведінкові моделі. На думку Ю. Ельстера, “коли люди слідують нормам, вони часто бажають уникнути відчуження іншими людьми - від косого погляду до остракізму” [14, с. 78]. Звідси слідує, що соціальний капітал пов'язаний не 3 зовнішніми, а внутрішніми санкціями у формі соціального контролю та відсутні спеціалізовані механізми примусу до виконання встановлених соціальних норм.

В умовах соціального контролю суб'єктами застосування санкцій (т. зв. гарантами норм) є спільнота чи суспільство загалом. Проте дії індивідів щодо виявлення порушень, усунення конфлікту між порушниками та контролерами є витратними. У випадку формальних інститутів джерелом покриття таких витрат є державний чи місцевий бюджети, неформальних - немає чітких джерел покриття витрат та стимулів для виявлення й покарання порушників. У цьому випадку використання інституту соціального капіталу $є$ більш економним, так як не передбачає оплати функцій добровільних контролерів. Останні застосовують санкції до порушників, не оцінюючи свої витрати та не вимагаючи компенсації в грошовій формі. Часто вони керуються внутрішніми мотивами для таких дій. У зв'язку з цим у науковій літературі для означення добровільних контрольних функцій зі сторони індивідів, які не спеціалізуються на примусі до виконання неформального інституту, використовують поняття “альтруїстичне покарання порушників" чи “дороговартісне покарання". Оскільки покарання порушників соціальних норм розглядають як суспільне благо, тому дана проблематика аналізується в термінах проблеми добровільної участі індивідів у виробництві суспільних благ чи подолання проблеми безбілетника.

Під час дослідження інституту соціального капіталу часто виникає питання: чому члени колективу карають тих, хто порушує норми? Застосування санкцій завжди є дорогим для того, хто їх застосовує незалежно від мотиву поведінки. Щонайменше це потребує витрат енергії та уваги, які можна використати для інших цілей. Крім того, через заборону взаємодіяти з людиною, яка піддана остракізму, втрачається можливість до взаємовигідної економічної співпраці. Один із варіантів пояснення полягає в тому, що поведінка контролера може бути засуджена з боку третіх осіб. Коли використовується норма, яка передбачає певну дію, то, як правило, існує і “метанорма", яка передбачає санкції проти тих, хто не слідує цій конкретній нормі. Водночас складаються також норми, які передбачають санкції для тих, хто не покарав порушників норми. Проте чим далі від порушення, тим менша ймовірність застосування санкцій. У зв'язку з цим соціальний контроль $\epsilon$ більш ефективним у невеликих і менш ефективним - у великих мережах. Відповідно деякі санкції, наприклад, на рівні громадянського суспільства, мають здійснюватися за іншими мотивами, ніж страх перед соціальним контролем. На думку А. Етціоні, “якщо люди слідують прийнятим у їх спільноті “роби/не роби”, оскільки розглядають норму як витрати чи обмеження, вони будуть порушувати іï, коли вигоди від іï дотримання будуть нижчими, ніж вигода від іï порушення, ризик виявлення якого невисокий... Якщо ж норми формують їх уподобання, люди намагатимуться слідувати їм, тому що така поведінка - джерело внутрішнього переконання” [16, с. 168]. Згідно 3 концепцією А. Етціоні трансформація норми із зовнішньої у внутрішню є процесом інтерналізації, унаслідок чого члени спільноти дотримуються соціальних норм навіть за умови, якщо порушення буде непомічене та не покаране. Під час аналізу альтруїстичного покарання домінантним $\epsilon$ 
функціональне пояснення, згідно $з$ яким люди карають порушників соціальних норм, оскільки це зумовлює підвищення добробуту групи, до якої належить гарант. Останнє забезпечує групі еволюційні переваги та є засобом адаптації до умов, які змінюються. Тим самим активне покарання "некооператорів" пояснюється його роллю в такій адаптації. Проте, на думку відомих науковців Р. Курцбана і П. де Сціолі, чітких експериментальних доказів “альтруїстичності” покарань немає, тому стримування (помста) залишається цілком ймовірною альтернативою [17].

Кожен інститут, у тому числі й соціальний капітал, є частиною інституційної структури суспільства, яка $є$ результатом тривалої еволюції відносин між його членами. За О. Уільямсоном “соціальна включеність” (у нашому випадку - відкритий соціальний капітал) є найвищим рівнем інституційної ієрархії [10]. Відкритий соціальний капітал є важливою складовою громадянського суспільства, без якої неможливе ефективне функціонування економічної системи в цілому. Якість інших інститутів залежить від соціальних зв'язків і структурування соціальної взаємодії, для яких він є своєрідним “матеріалом". На думку Нобелівського лауреата Е. Остром, “ми повинні бачити в інститутах - правилах гри - спосіб допомогти людям збільшити кредит довіри до інших, а також використання мереж як спосіб капіталовкладення в кращі інститути” [15, с. 70]. Така місія інституту відкритого соціального капіталу дає нам підстави розглядати його як економічний метаінститут, із якого в процесі еволюції формуються інші інститути, технології та рутини, як на мікро-, так і макрорівнях.

Соціальні норми та стереотипи поведінки змінюються повільно. У зв'язку з цим соціальний капітал $є$ одним із найбільш інерційних серед інститутів інституційної системи суспільства. Важливу роль у цьому відіграють групи спеціальних інтересів, що формують мережеві структури, траєкторія попереднього розвитку, ефект блокування тощо.

Розвиток соціального капіталу нерозривно пов'язаний із інституційним генотипом попереднього економічного порядку. У зв'язку з цим вивчення особливостей соціального капіталу в СРСР дозволяє пояснити тягар інституційного багажу та роль траєкторії попереднього розвитку у формування сучасної моделі господарювання.

Під час аналізу змін інституту соціального капіталу та його ролі в економічних процесах особливе значення має концепція дихотомії Веблена та інституційної інерції. "Дихотомія Веблена" (Веблена-Ейрса) - протиріччя, які виникають в процесі соціальних змін між динамічним розвитком технологій та інерційним розвитком інститутів (у тому числі соціального капіталу). Сучасні тенденції розвитку технологій випереджають зміни відповідних інститутів, тому спостерігається розрив між формуванням інституційної структури та швидко мінливими механізмами алокації ресурсів.

Для обгрунтування ролі інституту соціального капіталу в трансформації інноваційних компаній та розвитку стартапів у науковій роботі використовується "ефект засновника" (як елемент "ефекту пляшкового горла" або окремий випадок загальної проблеми “дрейфу генів” в еволюційній економіці). Аналогом дрейфу генів в соціально-економічному житті $є$ масштабні інституційні зміни. Згідно 3 “ефектом пляшкового горла" малі мережі або організації (наприклад, мікро- чи малі підприємства) швидше еволюціонують, проте нові їх характеристики (конкурентні переваги) будуть мультипліковані наступниками й з більшою ймовірністю поширяться на великі мережі. Це також знайшло своє відображення в теорії дифузії інновацій Е. Роджерса, де дифузія - процес, під час якого інновація з плином часу через певні канали поширюється серед членів соціальної системи [8, с. 192].

Значне місце в науковому дослідженні відіграє теорія груп спеціальних інтересів. Модель колективних дій М. Олсона є загальною теорією, яка може дати концептуальні рамки (фрейми) чи патерни для розуміння функціонування формальних субінститутів соціального капіталу. Процес еволюції інституту соціального капіталу ми частково будемо пов'язувати 3 формуванням та трансформацією груп спеціальних інтересів. У рамках нашої концепції виникають, припиняють існування, розширюються чи звужуються групи спеціальних інтересів як важливий елемент соціальних мереж.

За М. Олсоном будь-яка група (велика чи мала) діє з метою отримання суспільного блага, що є взаємовигідним для усіх ii членів. У своїй роботі “Логіка колективних дій” він розрізняє ексклюзивні/інклюзивні блага та групи. На його думку, ексклюзивне благо характеризується 
спільним споживанням, проте його споживання однією людиною зменшує обсяг споживання іншими, тому ексклюзивні групи вимагають високих бар`єрів для входу новачків та соціальної дискримінації нечленів групи. Інклюзивне колективне благо - це чисте суспільне благо, коли збільшення споживання з боку нових учасників групи не зменшує вигоди інших [7, с. 34-35]. Логіка такого поділу передбачає, що групи відрізняються за своїм ставленням до нових учасників. Наприклад, професійні союзи, які $\epsilon$ прикладом ексклюзивних груп, захищали “солідарність професійних інтересів” і водночас вимагали, щоб роботу не міг отримати нечлен від профсоюзу, що створювало умови, через які проникнення нових представників на ринок праці обмежувалося. В інклюзивних групах немає потреби виключати когось зі споживання, проте тут важлива реакція інших на економічну поведінку учасника мережі. Крім того, у своїй роботі він також виокремлює привілейовані, проміжні, неорганізовані та “забуті” групи. Ефективний інститут соціального капіталу передбачає формування саме інклюзивних груп спеціальних інтересів.

Не менш важливе значення для ефективного функціонування групи має пї величина. Коли мережа $\epsilon$ широкою, типовий учасник може вважати, що його голос не вплине на результат i незалежно від своєї позиції він буде змушений прийняти спільне рішення. Відповідно учасник спільноти не докладає достатньо зусиль для вивчення питання. Рішення зустрічі - це суспільні блага учасників і внесок кожного в їх виробництво буде меншим, чим більша кількість учасників групи. Цим пояснюється вища ефективність невеликих мереж. Малі групи діють рішуче й ефективніше використовують свої ресурси. На думку М. Олсона, “малі групи, як правило, використовують свою потенційну енергію, тоді як у великих групах сили, як правило, залишаються потенційними” [7, с. 48]. Це також частково дозволяє пояснити неефективність інституту громадянського суспільства під час голосування на виборах тощо.

М. Олсон також розрізняє групи з вузькими та широкими інтересами. Мережі груп вузьких спеціальних інтересів можуть мати несприятливий вплив на економічний розвиток через створення субоптимальних і неефективних інститутів. Такі групи спеціальних інтересів поступово формують інституційне середовище 3 вищими характеристиками інертності та створюють передумови для “соціального склерозу”. Основним ризиком у такому випадку є формування економічної системи сучасного меркантилізму або економіки владних груп, тобто невеликих ексклюзивних мереж, які отримують вигоду із такої інституційної організації економіки та суспільства. М. Олсон довів, що стабільні та довготривалі групи 3 вузькими інтересами своїми діями будуть сприяти збільшенню асинхронності, яка спричиняє системну кризу й руйнування інститутів. Тому ефективний економічний розвиток у довгостроковому періоді можливий у випадку, якщо в суспільстві формуються механізми, що періодично руйнують чи відновлюють структуру груп спеціальних інтересів, що еволюційно склалася в суспільстві. Процес оновлення мереж має знижувати асинхронність змін, визначає напрями та якість модернізаційних процесів.

Ефективність соціального капіталу як інституту та синергії кооперативної взаємодії можна розглядати за допомогою різних критеріїв, а саме через: 1) зниження трансакційних витрат і зменшення асиметрії інформації; 2) оцінку обмежень і можливостей для розвитку різних форм економічної активності та їх значення в забезпеченні економічного зростання; 3) роль соціального капіталу в забезпеченні суспільної ефективності в широкому сенсі: через участь спільнот у створенні суспільних благ, процесі збільшення різноманіття, складності, продуктивності економіки, реалізацію колективних кооперативних цінностей, забезпечення матеріального та морального добробуту людей; 4) його значення у забезпеченні інклюзивного економічного розвитку тощо.

У рамках нашого дослідження важливе значення має роль соціального капіталу в зменшенні трансакційних витрат. За Д. Нортом, трансакційні витрати - це витрати на оцінку корисних властивостей об'єкта обміну та витрати на забезпечення прав і примусу до їх дотримання [6]. Відповідно до класифікації російського науковця I. Капелюшникова трансакційні витрати поділяються на витрати: 1) пошуку необхідної інформації, 2) ведення переговорів (зокрема представницькі витрати, укладання та оформлення контрактів тощо), 3) на оцінку якісних характеристик благ, 4) специфікації і захисту прав власності (судові витрати, витрати на відновлення порушених прав та витрати внаслідок недостатньої їх специфікації), 5) опортуністичної поведінки [3, c. 51]. Як правило, опортунізм передбачає порушення соціальних норм: відповідальності, взаємності тощо. Це зумовлює додаткові витрати осіб, чиїми інтересами нехтує опортуніст. Негативні наслідки 
впливу трансакційних витрат на економічну взаємодію полягають у підвищенні вартості трансакцій, а також вони перешкоджають пошуку нових можливостей застосування наявних ресурсів, зміни чинних правил гри та не дозволяють вичерпати взаємні вигоди обміну.

Крім того, ми розглядаємо соціальний капітал як інструмент, за допомогою якого можна досягнути інклюзивний економічний розвиток, що серед іншого спирається на принципи сталого розвитку. У 2017 р. Уряд України представив національну доповідь “Цілі сталого розвитку: Україна", яка визначає базові показники для досягнення Цілей сталого розвитку (ЦСР). У доповіді представлені результати адаптації 17 глобальних ЦСР з урахуванням специфіки національного розвитку. Серед них: подолання бідності у всіх її формах, сприяння добробуту для всіх у будь-якому віці, поступальному, всеохоплюючому та сталому економічному зростанню, повній і продуктивній зайнятості та гідній праці для всіх, створення стійкої інфраструктури, сприяння всеохоплюючій і сталій індустріалізації та інноваціям; скорочення нерівності всередині країн і між ними; забезпечення відкритості, безпеки, життєстійкості й екологічної стійкості міст і населених пунктів; забезпечення переходу до раціональних моделей споживання i виробництва. Важливим інструментом для досягнення таких цілей $є$ консолідоване громадянське суспільство, що є проявом потужного відкритого соціального капіталу.

Висновки i перспективи подальших досліджень. Таким чином, узагальнення вище зазначеного дозволяє сформулювати наступне визначення соціального капіталу як метаінституту, що має дуальну природу (як сукупність неформальних (соціальних норм, довіри) та формальних (мереж) субінститутів), який є ресурсом для створення інших інститутів, визначає обмеження та економічні можливості для нових форм економічної активності, сприяє зменшенню трансакційних витрат, асиметрії інформації, проявів опортуністичної поведінки та відповідно забезпечує економічний розвиток нової якості (через збільшення різноманіття, складності, ефективності економіки, підвищення рівня соціальної згуртованості тощо).

\section{Джерела та література}

1. Институциональная архитектоника и динамика экономических преобразований /Под ред. А. Гриценко. Х.: Форт, 2008. 928 c.

2. Єлісєєва Л.В. Роль соціального капіталу в економічному розвитку: монографія/НАН України, ДУ “Інститут економіки та прогнозування НАН України”. К., 2019. 356 с.

3. Капелюшников Р.И. Экономическая теория прав собственности. М.: ИЭ АН СССР, 1990. 90 с.

4. Корнаи Я. Системная парадигма. Вопросы экономики. 2002. № 4. С. 17-34.

5. Нельсон Р., Уинтер Дж. Эволюционная теория экономических изменений. М.: Дело, 2002. 536 с.

6. Норт Д. Институты, институциональные изменения и функционирование экономики. М.: Фонд экономической книги “Начала", 1997. 180 с.

7. Олсон М. Логика коллективных действий. Общественные блага и теория групп. М.: ФЭИ, 1995. 174 с.

8. Роджерс Е. Дифузія інновацій. К.: ВД “Києво-Могилянська академія”, 2009. 591 с.

9. Степанов В.Н. Постнеклассическая методология исследования социо-эколого-экономических процессов. Науковий вісник Міжснародного гуманітарного університету. 2014. № 6. С. 56-59.

10. Уильямсон О. Экономические институты капитализма. СПб.: Лениздат, 1996. 702 с.

11. Хикс Дж. Теория экономической истории. М.: НП “Журнал Вопросы экономики”, 2003. 224 с.

12. Шумпетер Й. Капіталізм, соціалізм і демократія. К.: Основи, 1995. 528 с.

13. Шумпетер Й. Теорія економічного розвитку: дослідження прибутків, капіталу, кредиту, відсотка та економічного циклу. К.: ВД “Києво-Могилянська академія”, 2011. 242 с.

14. Эльстер Ю. Социальные нормы и экономическая теория. Thesis. 1993. Вып. 3. С. 73-91.

15. Ahn T., Ostrom E. Social capital and collective action. The Handbook of Social Capital/Castiglione D., Deth J., Wolleb G. (ed.). Oxford: Oxford University Press, 2007. P. 70-101.

16. Etzioni A. Social Norms: Internalization, Persuasion and History. Law and Society Review. 2000. Vol. 34. No. 1. P. $157-178$.

17. Kurzban R., De Scioli P. Adaptationist punishment in humans. Journal of Bioeconomics. 2013. February. P. 110-124. 


\section{References}

1. Gricenko, A. (2008). Institucional'naja arhitektonika i dinamika jekonomicheskih preobrazovanij [Institutional architectonics and dynamics of economic transformation]. Kharkiv: Fort [in Russian].

2. Yelisieieva, L. (2019). Rol' sotsialnoho kapitalu v ekonomichnomu rozvytku [The role of social capital in economic development]. Kyiv: Institute for economics and forecasting National Academy of Sciences of Ukraine [in Ukrainian].

3. Kapeljushnikov, R. (1990). Ekonomicheskaja teorija prav sobstvennosti [Economic theory of property rights]. Moscow: IE AN SSSR [in Russian].

4. Kornai, Ja. (2002). Sistemnaja paradigma [Systemic paradigm]. Voprosy jekonomiki - Economic issues, (4). - P. 17-34 [in Russian].

5. Nel'son, P., Uinter, Dzh. (2002). Evoljucionnaja teorija jekonomicheskih izmenenij [Evolutionary theory of economic change]. Moscow: Delo [in Russian].

6. Nort, D. (1997). Instituty, institucional'nye izmenenija i funkcionirovanie jekonomiki [Institutions, Institutional Change and Economic Performance]. Moscow: Fond jekonomicheskoj knigi "Nachala" [in Russian].

7. Olson, M. (1995). Logika kollektivnyh dejstvij. Obshhestvennye blaga i teorija grup [The logic of collective action. Public goods and group theory]. Moscow: FEI [in Russian].

8. Rodzhers, E. (2009). Difuzija innovacij [Diffusion of innovations]. Kyiv: VD “Kievo-Mogiljans'ka akademija" [in Ukrainian].

9. Stepanov, V. (2014). Postneklassicheskaja metodologija issledovanija socio-jekologo-jekonomicheskih processov [Post-classical methodology of research of socio-ecological-economic processes]. Naukovij visnik Mizhnarodnogo gumanitarnogo universitetu - Scientific Bulletin of the International Humanities University, (6). - P. 56-59 [in Russian].

10. Uil'jamson, O. (1996). Ekonomicheskie instituty kapitalizma [Economic institutions of capitalism]. SanktPeterburg: Lenizdat [in Russian].

11. Hiks, Dzh. (2003). Teorija ekonomicheskoj istorii [Theory of economic history]. Moscow: NP "Zhurnal Voprosy ekonomiki" [in Russian].

12. Shumpeter, J. (1995). Kapitalizm, socializm i demokratija [Capitalism, socialism and democracy]. Kyiv: Osnovi [in Ukrainian].

13. Shumpeter, J. (2011). Teorija ekonomichnogo rozvitku: doslidzhennja pributkiv, kapitalu, kreditu, vidsotka ta ekonomichnogo ciklu [Theory of economic development: the study of profits, capital, credit, interest and the economic cycle]. Kyiv: VD "Kiєvo-Mogiljans'ka akademija” [in Ukrainian].

14. El'ster, Ju. (1993). Social'nye normy i jekonomicheskaja teorija [Social norms and economic theory]. Thesis, (3). - P. 73-91 [in Russian].

15. Ahn, T., Ostrom, E. (2007). Social capital and collective action. The Handbook of Social Capital. Oxford: Oxford University Press [in English].

16. Etzioni, A. (2000). Social Norms: Internalization, Persuasion and History. Law and Society Review? (34). P. 157-178 [in English].

17. Kurzban, R., De Scioli, P. (2013). Adaptationist punishment in humans. Journal of Bioeconomics. February. - P. 110-124 [in English].

Стаття надійшла до редакції 19.05.2021 р. 